Experience Report

\title{
Workshops with teachers: health education for management with adolescents *
}

\author{
Oficinas com professores: educação em saúde para o manejo com adolescentes \\ Talleres con profesores: educación en salud para el manejo de adolescentes

\section{Rodrigo Eurípedes da Silveira ${ }^{1}$, Nayara Araújo dos Reis ${ }^{2}$, Álvaro da Silva Santos ${ }^{3}$, Maritza Rodrigues Borges ${ }^{4}$, Ariadne da Silva Fonseca ${ }^{5}$}

\begin{abstract}
Objective:To describe the experience during the execution of an extension project, which used a municipal school setting in Uberaba-MG. Methods:Experience report using health education strategies, focused on workshops with teachers ofElementary School.Results:We conducted seven meetings with 30 teachers from the three school shifts, initially seeking connection and situational diagnosis. In five other sessions we worked with the themes teachers considered to be the necessities, and in the last encounter we presented a case study that allowed verification of learning.Conclusion:Despite technical, structural and human difficulties, the richness of the discussions raised and the reports from teachers, confirmed the success of the project, reaching the value of a social and interventionist character.
\end{abstract}

Keywords: Faculty; Adolescents; Sexuality; Health Education

\section{RESUMO}

Objetivo: Descrever a experiência vivida durante a execução de um projeto de extensão, que utilizou o cenário de uma escola municipal de Uberaba-MG. Métodos: Relato de experiência, utilizando estratégias de educação em saúde, focadas na realização de oficinas com professores do Ensino Fundamental. Resultados: Realizaram-se sete encontros com 30 professores dos três turnos escolares, buscando no primeiro momento o vínculo e o diagnóstico da situação. Em outras cinco sessões, foram trabalhadas as temáticas consideradas como necessárias aos docentes e, no último encontro, foi apresentado um estudo de caso, o que possibilitou a verificação do aprendizado. Conclusão: Apesar das dificuldades técnicas, estruturais e humanas apresentadas, a riqueza das discussões suscitadas e o relato dos professores, comprovaram o sucesso do projeto, alcançando um valor de caráter social e intervencionista.

Descritores: Docentes; Adolescente; Sexualidade; Educação em saúde

\section{RESUMEN}

Objetivo: Describir la experiencia vivida durante la ejecución de un proyecto de extensión, en el que se utilizó el escenario de una escuela municipal de Uberaba-MG. Métodos: Relato de experiencia, utilizando estrategias de educación en salud, centralizadas en la realización de talleres con profesores de Enseñanza Fundamental. Resultados: Se realizaron siete encuentros con 30 profesores de los tres turnos escolares, buscando en el primer momento el vínculo y el diagnóstico de la situación. En otras cinco sesiones, fueron trabajadas las temáticas consideradas como necesarias para los docentes y, en el último encuentro, se presentó un estudio de caso, el que posibilitó la verificación del aprendizaje. Conclusión: A pesar de las dificultades técnicas, estructurales y humanas presentadas, la riqueza de las discusiones suscitadas y el relato de los profesores, comprobaron el éxito del proyecto, alcanzando un valor de carácter social e intervencionista.

Descriptores: Docentes; Adolescente; Sexualidad; Educación en salud

\footnotetext{
${ }^{1}$ Nurse. Master's in Health Sciences at the Institute of Medical Assistance to the State Public Servants of São Paulo (Instituto de AssistênciaMédicaaoServidorPúblicoEstadual de São Paulo, LAMSPE). Professor ofthe Federal Universityof Triângulo Mineiro (Universidade Federal do Triangulo Mineiro, UFTM)Uberaba, Minas Gerais, Brazil.

${ }^{2}$ Nurse at UNIMED Uberaba, Minas Gerais, Brazil.

${ }^{3}$ Nurse. Public Health Specialist.Master's in Health Services Administration.Doctorate in Social Sciences. Post Doctorate in Social Work. Professorof Undergraduate Nursing and of the Master's of Health Care at the UFTM.

${ }^{4}$ Nurse. Master's in Health Sciences from theLAMSPE. Nurse in the Municipal Health Department of Uberaba, Minas Gerais, Brazil.

${ }^{5}$ Nurse. Master's and doctorate in nursing. Coordinator of the publications of the Network of São Camilo Hospitals of São Paulo, Brazil.
} 


\section{INTRODUCTION}

Adolescence is one of the most significant stages in human development, infused by a phase of uncertainty and transition, manifestedby intense physical growth and development, accompanied by physiological, psychological and social altercations ${ }^{(1)}$. In the course of these changes, the absence of adequate guidance, as family, school and society can pose physical, psychological, and social risks for the adolescent ${ }^{(2)}$.

It is in this context that the school institution acquires fundamental importance in this phase of life of the youth, assisting in the formation of their characters and in the construction of their personalities. In addition, the school is considered the second principle nucleus of human life, where the individual spends a major part of his time, and experiments with a series of interpersonal relationships. While at school, the youth comes into contact with other adult references in addition to his parents, -the teacher. This one assumes the role of the main communication channel between knowledge and students and, also, as professionals involved with the formation of critical thinking and the construction of citizenship ${ }^{(3)}$.

However, the teacher in Brazil, especially when employed in the public school, faces diverse difficulties, including: the accumulation of functions such as building health habits, psychological counseling of studentsand bureaucratic tasks that, associated with lack of autonomy, infrastructure and low remunerationconstitute a situation of social, psychological and biological vulnerability of this professional ${ }^{(4,5)}$. These factors contributes to lack of professional motivation and interest in seeking new teaching strategies and pedagogical training, aggravated by the lack of discipline of students and lack of recognition and value in society ${ }^{(6)}$.

From the perspective of building a space of reflection-action, with a foundation in technical-scientific and popular knowledge ${ }^{(7)}$, health education presents itself as a key strategy in the process of transformation of behavior ${ }^{(8)}$,mediated by educational practices that exalt the autonomy of individuals in the conduct of their lives. The practice attributed to the professional nurse intends to encourage promotion, prevention and health maintenance, capable of bringing about individual changes and readiness to act in the family and in the community, aligned to the implementation of public policies, contributing to social transformation ${ }^{(7,8)}$.

As facilitator of the process of health education through the articulation between the University and the community as a whole, the university extension intends to align the activities of teaching and research developed within the academic environment to the real demands of society, especially collaborating in the development of healthy habits and the strengthening of citizenship ${ }^{(9)}$.
Consonant with these perspectives, the present studyaimed to describe the experience of the insertion of health education strategies, especially operationalized by the professional nurse in the school setting, based in the execution of an extension project, in order to share the experience of nursing practice in workshops with primary school teachers.

\section{METHODS}

This experience report reflects the results and perceptions of the members of the Extension Project, "Tuvenile protagonism as a strategy of family and community intervention in the residential neighborbood 2000," conducted through the promotion of

the Research and Education Foundation of Uberaba, Minas Gerais, Brazil (FUNEPU), Federal University of TriânguloMineiro (UFTM). The initiative aimed to approximate the boundaries of the university for health education in the school environment.

The referred project was conducted between the period of August 2010 and March 2011, subdivided into two phases of activity: the first considering the teachers, and the second contemplating the students in the seventh and eighth grades of the three shifts of the Esther LimirioBrigagão Municipal School, located in residential neighborhood 2000 in Uberaba, Minas Gerais.

This work refers to the first phase of that project-theexperience with the teachers, and the second phase, with thestudentswas described in another article.

The experience was based on the description of the strategies of health education, mediated by the workshops targeted at primary school teachers in order to offer a better and adequate didactic management for adolescents in primary education, on topics related to adolescence and sexuality.

Thus, the following steps were established: (a) initial questioning, from the prior knowledge and pedagogical experiences / difficulties of the participants, (b) choice of themes (by teachers) to be covered in the meetings, (c) presentation of the content through workshops, (d) critical reflection, discussion and reports from participants, and (e) socialization and evaluation of the activities.

In this research, we used participatory training strategies, aligned to the concept of health education, with the use of workshops. To support these activities were citedCarvalho, Rodrigues and Medrado ${ }^{(10)}$, who understood a workshop as "a structured work with groups, independent of the number of encounters, that is focused around a central question that the group intends to develop, in a social context. The development that is sought in the workshop is not restricted to rational reflection, but involves the subjects in a comprehensive manner; ways of thinking, feeling and acting. 
The themes selected for the workshops were: violence, bullying, sexuality, teenage pregnancy, STDs / AIDS, alcohol and drugs. In addition to the teachers, the directors and the orientation service / pedagogical supervision of the school participated in the choice of themes, although that ones have supported only in logisticswork and also with suggestions, not being objectsof intervention.

In order to contemplate the three shifts of work, were conducted weekly meetings in 2 alternative times, between the intervals of morning-evening and afternoon-night, lasting an average of two hours each. Thus, seven workshops were conducted with each group.

\section{RELATING THE EXPERIENCE}

The region where the school was located had high levels of crime and social vulnerability, reflecting high rates of adolescent pregnancy and consumption of alcohol and drugs by the young population ${ }^{(1)}$. In order to promote educational strategies targeted at adolescents in the school environment, several studies have been conducted, especially addressing themes related to sexuality ${ }^{(1,9)}$ and the improper use of drugs ${ }^{(11)}$.

It is worth mentioning thatstill are insufficient realizationsof workshops directed at teachers, particularly in Brazil. Internationally, investigations and training of family daycare centers were conducted with educators to promote the social and emotional wellbeing of the child in Melbourne ${ }^{(12)}$; focus groups were conducted with parents and teachers, to approach the dimensions and causes of risk behaviors in children and youth in Jamaica ${ }^{(13)}$; the "Developmental Coordination Disorder" was approached by occupational therapists in workshops with educators and parents of children and adolescents in Canada ${ }^{(14)}$; and training strategies for teachers were used to improve the practice of physical education in the United States ${ }^{(15)}$.

In this research, for both rounds, the themes andactivities proposedfor each workshop were the same,following a schedule that defined what would be practicedin subsequent meetings, based on the definition of needsraised at the first meeting by the teachers.

The workshops were held by extension studentworkersand the teachers involved in the project.Counted also withthe logistical support of professionals from the Family Health Team of the neighborhood in question, directors and the pedagogical coordination of the school.

To mobilize the group around the proposal, we applied certain dynamics that contributed significantly to the formation of the bond between the subjects, in addition to offering a perspective of their aspirations in view of the reality.

In this sense, the firstworkshop was intended to introduce the subjects engaged in the project; make a survey ofneeds on the part of teachers in the management withschool adolescents; in addition we prepared aplan ofeducational interventionsfor meeting that needs.

The second workshop aimed to assess in the teachers optical, the psychosocial aspects and self-knowledge of their conditions, through a simple dynamic, the "dynamic of the banner" (self knowledge): the group was directed to make its individual banner, in the form of drawing or writing, by answering six questions, namely:

- What is your major individual success?

- What would you like to change in yourself, as a professional?

- What are your greatest strengths as a teacher?

- In what activities do you consider yourself to be very good?

- What is most valued in life?

- What are the difficulties or facilities that you encounter in your profession?

The activity intended to stimulate participants' creativity by providing an environment for the exchange of experiences, and to observe the perception they had of themselves, alerting them to their actual working conditions relative to their desired perspectives.

At the third meeting, based in the "traffic light dynamics" -which used a poster containing this traditional colors. That consisted of attributing the same colors to questions relating to the themes to be worked on, according to the difficulty of addressing each theme: (green: easy, yellow: intermediate and red: impractical). Were worked onthe themes of intra- and extra-household violence and bullying, in which faculty shouldraise the questions that participants have experienced inclassroom or even those questions in eminenceto be made, they would have difficulties to answer.

Subsequently, we performed a simulated jury about the reality already experienced in the school, narrated by the adolescent students, which revealed profound gaps in teacher knowledge, especially with regard to coping with instances of maltreatment among students on school premises.

The fourth encounter included the discussion about alcohol and drugs, aptitude / vocational orientation and teaching - learning. The teachers were divided into three groups to debate, leaning in journal, papers and book publications focused in the best strategies for proceedingwith in these cases, emphasizing the role of the schoolon these issues, through simulations, in which the teachers should to "dramatize" situationsthey bring any questions or difficulties, pointingstill, the best way to deal with these facts.

The fifth encounter was called "developing the trajectory and selecting strategies", in which the potential interventions were studied, comparing the analysis with the theoretical support for action, that is, evaluating what were the tools that contributed to the solution of the identified problems that had been addressed in previous workshops. 
The second activity conducted in the fifth workshop used the "dynamic of the doll", which required a division of the teachers into six groups. Were printed images that represented a portion of the doll's body (head, torso, arms, hands, legs and feet).Each group was responsible for one part, which contained a question related to the daily lives of the participants. The members of each group should elaborate in set, a response that demonstrate how they usually reacted to that situation, and how they could contribute to its function, in relation to the school and its students. Subsequently, a discussion forum was conducted, followed by reflection of the group members, who shared their observations and perspectives to improve their professional performance within the themes addressed. As the issues were discussed,we proceeded to assemble the doll's form, till the end.

The guiding questions of the "dynamic of the doll" were:head - how do you see the fulfillment of social roleof the school among teaching and student learning?

Torso - how the group sees the violence in the students and their familiescontext? Arms-Do you see your school contributing to the proposal of professional student training (adolescent) and the building of anew citizen? HandsIn your opinion, how are the healthy lifestyle issues (hygiene, foodappropriate physical activity, leisure and other) of the students andtheir families? Legs - what is the reality of children andyoung people from the school in relation to gender and sexuality? Feet- what is the perception of the group about the use of drugs and alcoholfor children and teenagers from the school and their family context?

In the next step, which was called "following and acting", the intervention of strategy development was conducted, planned for the diagnosed situation. During the project, it was found that the most difficult issues for educators were: sexuality, teen pregnancy and STD / AIDS. Therefore a health education activity was prepared, with the support of professionals in the Family Health Unit of the neighborhood, as well as other invited professionals, through a strategy of information and dialogue, teachers had their doubts addressed, learned about the themes, and gained new perspectives and methodologies for addressing the themes.

Finally, at the last workshop, by way of assessment a clinical case was presented that contained all the situations of vulnerability presented, in addition to the problems that had been worked on in the workshops. In this step, the participants identified possible solutions to problems, making necessary referrals, and showing adequate behaviors for the case. Additionally, there was a dynamic for creating a comfortable relationship between the teachers, favoring contact between everyone, including people who did not even know each other within the institution. We finished the encounters with the step "following the trajectory", in which an evaluation was made of the encounters through the report of its participants.
The reported experience showed that there was a disconnection between the health services, social assistance and education. In addition, in the very institutions that supported the adolescent, there was a lack of material, technical and human resources, factors that limit the quality of the service provided. Besides that possibilities to identify some teachers, especially those disciplines distant from biological knowledge, demonstrated ignorance of the progress of adolescence and its relationship with the school.

To enable the occurrence of a student-teacher relationship with positive characteristics in the school environment, it is necessary for teachers to have knowledge of the transformations inherent to adolescence, and the risks and vicissitudes linked to this phase of human development. From this perspective, the importance of training regarding the themes of adolescence, and the dialogue in the classroom, should be reinforced in order to prevent injuries within the lives of young people in situations of risk ${ }^{(10,16)}$.

It is common knowledge that the school is the social environment in which the individual spends most of his life, and which is one of the main elements for interpersonal contacts. As such, it is considered the second most important nucleus of the human life, as it works to build character, social responsibility and fundamentals of citizenship, and to prepare the individual for adult life through knowledge ${ }^{(17)}$.

The difficulties experienced in the reality investigated also referred to the teachers' life and work conditions. In research conducted, which considered the quality of life of the teachers, aspects most affected were vitality $(60 \%)$ and mental health $(69.2 \%)$. Moreover, such professionals were exposed to stressful factors linked to social and economic contexts in that community that ranged from the difficulty of transportation, to access for health problems within the neighborhood, in a general way ${ }^{(3)}$.

With regard to the initiative, several authors support the view that a major strategy for disease prevention is to encourage self-care, through appropriate training and adequate guidance, which is embedded in health education. In a study conducted with pregnant Chilean women about the knowledge and practices associated with sexually transmitted diseases and HIV / AIDS, the importance of creating dialogue groups and other strategies that encouraged health promotion and safe practices for self-care were reinforced, using a greater approximation of social institutions, such as schools, health institutions and social assistance ${ }^{(17)}$.

A study conducted in Buenos Aires considered the opinion of school principals regarding student drug dependence, demonstrated the need for a better approach to the problem of drug abuse in schools, in collaboration with other institutions and experts, providing training for their employees in health, psychology and group dynamics, as well as the development of the conditions of 
empathy, human warmth and amplification of the vision of linkages with the school population ${ }^{(18)}$.

Furthermore, we refer to the report of parents faced with the sexual orientation of their children, as investigated by Almeida and Centa ${ }^{(19)}$, in which they stressed the importance of dialogue and frank conversation between parents and children; the difficulty of communication between parents and children; parental difficulties related to the education received. The authors stress yet the importance of education shared with the school, understood to be the main ally in the sexual education of children, and it was explained that this institution relayed much of the information possessed by the children.

Although the same structure and a priori content of the encounters was maintained, prior to the implementation of the workshops, different approaches were needed for the two groups (morning and night) based on the perceptions of each workshop.

Diverse situations were observed, such as the lack of commitment of some teachers with the agreed schedule; emotional imbalance of some teachers; several interruptions of staff and students in the room where the workshops were taking place; lack of technical support and adequate equipment to perform all proposed activities, among others. However, despite getting in the way of the development of some workshops, these situations did not overshadow the final results.

Still, the receptivity of the school coordinators and the incentives for completion of the project should be noted, given the shortage of this type of initiatives, in addition to the assent of the majority of the professionals and teachers, who endeavored to reflect on their daily lives. As an outside objective of this project, the activities and techniques developed in the workshops assisted in the awakening of the personal skills of the teachers, their aspirations and reflections about management with the students, and helping them to understand their responsibility regarding the health issues of adolescents in situations of risk, broadening their professional vision and their experience as an educator in society.

\section{FINAL CONSIDERATIONS}

Despite the preconception towards adolescents, named by some as a "lost generation, uncompromising and alienated", important social work was performed with the intention of revealing the actual situation of vulnerability of this age group, aimed to devising effective strategies for combating problems commonly experienced by these young people.

Many times the sexual orientation takes place in a segmented manner, and the young construct their sexuality and many other aspects of their character in the experimental relationships with friends and in digital media, creating deviations of conduct and constructing questionable values. Therefore, a more profound interaction is necessary between school, family and community, beyond the support of trained personnel in health and social assistance, to meet all the desires and necessities of building a young citizen.

As such, the development and implementation of this work, the care in choosing the proposed activities and their development within each workshop, and group activity were conducted with the objective of promoting interaction and participation of the entire school institution. This was especially true for the teachers, who dealt directly and daily with the adolescents, so that they could express their concerns, needs and experiences, constructing a partnership of exchange with the coordinators, expanding and replicating the knowledge presented.

The execution of a project of this nature is a form of cooperation in the awareness of adolescents and in making decisions about their lives, character and constitution of citizenship, in the comprehension of sexuality and drug use, in the knowledge of different careersand vocational aptitude, among others, for that young peoplecan get tools that ensure them behaviorsthat do not undermine their relations, noryour health. The role of the teacher in the approach of thesethemes is important, but requires at the same time anadditional preparationthat extension proposals on the health education interfacemay include, in particular, as social contribution at the University.

The richness of the discussions raised and the report of parents, teachers, school staff and some students demonstrated the achievement of project objectives that had a social and interventional nature, using social and structural resources of the public school system for the construction of a new local educational reality that can and should be replicated. Furthermore, it emphasized the growth and professional development of the team that developed the project, supporting the creation of a space for questioning the issues related to adolescence, and the social responsibility of nurses and health educators.

The relationship of a public university and a Primary School was important in the sense of the mutuality of contributions, such as: learning, partnerships for interventions, approximation of the training institution for teachers and health educators, among others.

This work points as recommendation that this experience would be applied in other school spaces, with teachers who deal with adolescents, ascited above, this professional exercises an important role inconstruction of citizenship of the individual in this life cycle,loaded of vulnerabilities, which can be understoodand best faced, if the teacher is able tosupport and guide their students. 


\section{REFERENCES}

1. Silveira RE, Reis NA, Santos AS, Borges MR, Soares SM. Oficinas com adolescentes na escola: uma estratégia de educação em saúde. Nursing (São Paulo). 2011; 14 (157):334-8.

2. Jardim DP, Brêtas JR. [Sexual orientation in school: conception of the teachers from Jandira - SP]. Rev Bras Enferm. 2006; 59(2): 157-62. Portuguese.

3. Silveira RE, Reis NA, Santos AS, Borges MR. [Quality of life of elementary school teachers in a Brazilian municipality. Rev Enferm Ref. 2011; 3(4):115-23. Portuguese

4. Linhares $C$, organizador. Os professores e reinvenção da escola: Brasil e Espanha. São Paulo: Cortez; 2001.

5. Jardim R, Barreto SM, Assunção AA. [Work conditions, quality of life, and voice disorders in teachers]. Cad Saúde Pública. 2007; 23(10): 2439-61. Portuguese

6. Vedovato TG, Monteiro MI. [Socio-demographic profile and health and working conditions of teachers of nine state of São Paulo public schools]. Rev Esc Enferm USP. 2008; 42(2): 290-7. Portuguese

7. Machado MF, Monteiro EM, Queiroz DT, Vieira NF, Barroso MG. [Integrality, health professional education, health education and sus proposals - a conceptual review]. Ciênc Saúde Coletiva. 2007; 12(2):335-42. Portuguese.

8. Cervera DP, Parreira BD, Goulart BF. [Health education: perception of primary health care nurses in Uberaba, Minas Gerais State]. Ciênc Saúde Coletiva. 2011; 16 supl 1: 1547-54. Portuguese.

9. Brêtas JR, Silva CV. [Sexual orientation for adolescents: report of experience]. Acta Paul Enferm. 2005; 18(3): 32633. Portuguese.

10. Carvalho AM, Rodrigues CS, Medrado KS. WWorkshop in human sexuality with adolescents]. Estud Psicol (Natal). 2005; 10(3): 377-84. Portuguese.

11. Corradi-Webster CM, Esper LH, Pillon SC. Nursing student participation in a community project to prevent drug abuse among teenagers. Acta Paul Enferm. 2009; 22(3): 331-4.

12. Davis E, Williamson L, Mackinnon A, Cook K, Waters E, Herrman H, et al. Building the capacity of family day care educators to promote children's social and emotional wellbeing: an exploratory cluster randomised controlled trial. BMC Public Health. 2011; 11(1): 842.

13. Baker-Henningham $H$. Transporting evidence-based interventions across cultures: using focus groups with teachers and parents of pre-school children to inform the implementation of the Incredible Years Teacher Training Programme in Jamaica. Child Care Health Dev. 2011;37(5):649-61.

14. Missiuna CA, Pollock NA, Levac DE, Campbell WN, Whalen SD, Bennett SM, et al. Partnering for change: an innovative school-based occupational therapy service delivery model for children with developmental coordination disorder. Can J Occup Ther 2012;79(1): 41-50.

15. Kulinna PH, McCaughtry N, Martin J, Cothran D. Effects of continuing professional development on urban elementary students' knowledge. Res Q Exerc Sport. 2011 Sep;82(3):580-4.

16. Villegas N, Ferrer L, Cianelli N, Miner S, Lara L, Peragallo N. Conocimientos y autoeficacia asociados a la prevención del VIH y SIDA en mujeres chilenas. Invest Educ Enferm. 2011; 29(2): 222-9.

17. Maio Braga ER, Alcaide Spirito C. Una investigación sobre la importancia de la educación afectivo-sexual en las escuelas. Rev Ibero-Am Estud Educ. 2010; 1(1):18-36.

18. Segovia NS, Gonçalves MF. Los espacios escolares para la prevención de la drogodependencia: concepción de directivas de escuelas secundarias. Rev Latinoam. Enferm. 2011;19 (No Espec):782-8.

19. Almeida AC, Centa ML. Parents experience with de sexual education of their children: implications for nursing care. Acta Paul Enferm. 2009; 22(1): 71-6. 